\title{
Effects of Abscisic Acid and Salicylic Acid on Gene Expression in the Antiviral RNA Silencing Pathway in Arabidopsis
}

\author{
Mazen Alazem ${ }^{1,2,3}$, , Kook-Hyung Kim ${ }^{1,2,4, * \mathbb{C}}$ and Na-Sheng Lin ${ }^{3, *}$ \\ 1 Department of Agricultural Biotechnology, College of Agriculture and Life Sciences, \\ Seoul National University, Seoul 08826, Korea; m.alazem@gmail.com \\ 2 Plant Genomics and Breeding Institute, College of Agriculture and Life Sciences, \\ Seoul National University, Seoul 08826, Korea \\ 3 Institute of Plant and Microbial Biology, Academia Sinica, Taipei 11529, Taiwan \\ 4 Research Institute of Agriculture and Life Sciences, College of Agriculture and Life Sciences, \\ Seoul National University, Seoul 08826, Korea \\ * Correspondence: kookkim@snu.ac.kr (K.-H.K.); nslin@sinica.edu.tw (N.-S.L.)
}

Received: 30 April 2019; Accepted: 21 May 2019; Published: 23 May 2019

\begin{abstract}
The RNA silencing pathways modulate responses to certain stresses, and can be partially tuned by several hormones such as salicylic acid (SA) and abscisic acid (ABA). Although SA and ABA are often antagonistic and often modulate different stress responses, they have similar effects on virus resistance, which are partially achieved through the antiviral RNA silencing pathway. Whether they play similar roles in regulating the RNA silencing pathway is unclear. By employing coexpression and promoter analyses, we found that some ABA- and SA-related transcription factors (TFs) are coexpressed with several $A G O, D C L$, and $R D R$ genes, and have multiple binding sites for the identified TFs in the queried promoters. ABA and SA are antagonistic with respect to the expression of AGO1 and $R D R s$ because ABA was able to induce these genes only in the SA mutant. Nevertheless, both hormones showed similarities in the regulation of other genes, for example, the induction of $A G O 2$ by $\mathrm{ABA}$ was $\mathrm{SA}$-dependent, indicating that $\mathrm{ABA}$ acts upstream of $\mathrm{SA}$ in this regulation. We inferred that the similar effects of ABA and SA on some genes resulted in the redundancy of their roles in resistance to bamboo mosaic virus, but that the two hormones are antagonistic with respect to other genes unrelated to their biosynthesis pathways.
\end{abstract}

Keywords: abscisic acid; salicylic acid; crosstalk; RNA silencing pathway; bamboo mosaic virus

\section{Introduction}

Plants employ hormones to tune their responses to environmental stimuli or developmental changes. Several hormones, including abscisic acid (ABA) and salicylic acid (SA), exhibit antagonistic interrelations that help plants balance their responses in order to limit the associated fitness costs. ABA is well-known for its role in plant responses to abiotic stress and for its multifaceted roles in plant-pathogen interactions [1-3]. SA, in contrast, has long been known to regulate plant defenses against biotrophs by priming systemic acquired resistance [4].

Although ABA and SA exhibit antagonistic interrelations in response to biotic and abiotic stresses [5-8], a few reports indicated that they share some integrative effects in modulating specific responses. In guard cells, for example, the SA signaling pathway merges with the ABA signaling pathway through $\mathrm{Ca}^{2+}$-dependent protein kinases to regulate stomatal closure [9]. Regarding resistance to viruses, both hormones have been reported to increase plant resistance to several pathogenic viruses partially through the RNA silencing pathway [10-13]. For instance, ABA regulates the expression of 
argonautes (AGO) 1, 2, 3, and 4 and the microRNA 168a [3,14], and induces resistance to infection by bamboo mosaic virus (BaMV), mainly through its effects on AGO2 and AGO3 [3]. ABA and AGO2 are also involved in resistance to potato virus X (PVX) in Arabidopsis thaliana. PVX replicates very weakly in A. thaliana due to the effect of AGO2 on resistance [15], and impairment of the ABA pathway reduces the accumulation of $A G O 2$ and allows PVX to accumulate and move systemically [3]. SA also induces the expression of RNA-dependent RNA polymerase (RDR) 1 in A. thaliana and contributes in resistance to plum pox virus by enhancing the production of virus-derived short-interfering RNAs (vsiRNAs) [13,16,17]. Nevertheless, the effects of ABA and SA on the antiviral RNA silencing pathway are incompletely understood, and there is little information of whether or how these hormones affect the majority of the genes involved in this pathway. The key genes in the RNA silencing pathway include the dicer-like $(D C L), R D R$, and $A G O$ gene families $[18,19]$. There are several other genes that maintain the integrity of the RNA silencing pathway $[18,19]$. However, the diversity and the proposed redundancy of several genes in the AGO, DCL, and RDR families have motivated us to investigate the involvement of these genes in ABA- and SA-mediated effects in Arabidopsis.

Given that ABA and SA are antagonistic to each other in response to abiotic stress and nonviral infections (bacterial and fungal), but share some similarities in inducing resistance/tolerance to viral infections; the objective of the current research was to determine how SA and ABA regulate genes involved in the antiviral RNA silencing pathway and whether the two hormones act in a parallel, antagonistic, or hierarchical manner in regulating the targeted genes. To accomplish this, we used PlantPan 2.0 to conduct coexpression analyses of SA- and ABA-related transcription factors (TFs) that may regulate genes in the $A G O, D C L$, and $R D R$ families. PlantPan 2.0 contains a large number of experimentally verified TF matrices as well as coexpression profiles of TFs and their target genes under various conditions [20]. We measured the expression of $A G O, D C L$, and RDR genes in SA- or ABA-treated wild type (WT) A. thaliana seedlings and in seedlings of the SA-mutant sid2-1, ABA-mutant aao3, and their double mutant sid2-1:aao3. Finally, we determined how impairment of the SA and ABA pathways affects plant susceptibility to BaMV, which is a potexvirus [21] with a positive-sense single-stranded RNA genome [22,23] that is packed in flexible filamentous particles [24]. To study plant-virus interaction, most researchers have used mature plants (usually 25 days old for Arabidopsis) and have collected samples 5 to 20 days postinfection. As a consequence, it remains unclear how younger plants respond to virus infection and hormone treatments. In this study, we used 6-day-old $A$. thaliana seedlings to investigate the effects of ABA and SA on the antiviral RNA silencing pathway. Our results showed that $\mathrm{ABA}$ and $\mathrm{SA}$ have similar positive effects on the expression of several $A G O$ genes, with one exception (ABA-induction of $A G O 2$ was found to be SA-dependent). On the other hand, both hormones exhibited mutual antagonism of $A G O 1$ and RDR expression in that ABA clearly induced those genes in the SA mutant sid2-1. The effects of these hormones on the expression of RNA silencing genes might be spatiotemporally regulated because the responses of some genes differ depending on tissue and plant age.

\section{Results}

2.1. Binding Sites of Several TFs Regulated by ABA and SA Are Located in the Promoter Regions of Genes Belonging to the AGO,DCL, and RDR Families

PlantPan 2.0 provides a large number experimentally verified matrices of TFs and their binding sites. This tool employs microarray expression data obtained from plants under different biotic/abiotic stresses, at different developmental stages, and under various hormone treatment conditions (Table S2) [20]. These public microarray data are compiled in the ExPath 2.0 expression database [25], and, because it offers coexpression analyses, ExPath can be used to determine whether genes are coexpressed under any specific condition.

When hormone treatment or biotic-stress conditions were selected, our coexpression analyses revealed that several ABA- or SA-related TFs can be coexpressed with genes in the AGO, DCL, and RDR families (Table 1). Almost all of these genes were determined to have at least two coexpressed 
TFs that are ABA- or SA-regulated. Only RDR6 lacked an SA-related coexpressed TF. Except for SA-regulated TGA2, TGA4, TGA6, and OBP1, there was no unified set of TFs that could bind to the same genes (Table 1). Most of the identified SA- and ABA-related TFs have positive regulatory roles in their corresponding signaling pathway; the exceptions are ATAF1 and HB33, which have negative roles in the ABA signaling pathway [26-28] (Table 1). The identified TFs modulate ABA- or SA-mediated responses depending on the tissue, developmental stage, or stress condition. These data suggest that, depending on the type of stress, ABA or SA may regulate plant response partially/collaboratively through the RNA silencing pathway. It should be noted that PlantPAN 2.0 lacks coexpression profiles for AGO6 due to the absence of a probe targeting AGO6 in the Affymetrix GeneChips microarray sourced from the Arabidopsis information resource (TAIR) database. In addition, we could not detect any expression of $A G O 5$ and $A G O 9$ in the 8-day-old mock or hormone-treated seedlings using several pairs of primers (data not shown). This was confirmed using the Arabidosis eFP browser, which offers expression data of Arabidopsis genes at any developmental stage (http://bar.utoronto.ca/efp2/).

Next we scanned the promoter regions of $A G O, D C L$, and $R D R$ genes for transcription factor binding sites (TFBSs) of the previously identified TFs. The scan showed that all promoters have multiple binding sites for the identified TFs, indicating that these genes can be regulated by both ABA and SA (Figure 1). Because the TFs TGA2, TGA4, TGA5 TGA6, ICE1, and HB33 have several binding sites in the promoters of several genes, the TFBSs were separately visualized (Figure S1). 
Table 1. Transcription factors that are involved in the regulation of ABA or SA responses and that can be coexpressed with silencing-related genes: TF: Transcription factor; Acc. No.: Accession number; ABA: abscisic acid; JA: Jasmonic acid; SA: salicylic acid; Et: Ethylene. References: [29] (Nakashima et al., 2006), [30] (Delmas et al., 2013), [31] (Acevedo-Hernandez et al., 2005), [32] (Kaliff et al., 2007), [33] (Shkolnik-Inbar and Bar-Zvi, 2010), [34] (Shu et al., 2013), [35] (Feng et al., 2014), [36] (Lopez-Molina et al., 2001), [37] (Carles et al., 2002), [38] (Bensmihen et al., 2002), [39] (Lopez-Molina et al., 2002), [40] (Finkelstein et al., 2005), [41] (Kim et al., 2012), [42] (Seo et al., 2010), [26] (Jensen et al., 2008), [27] (Wu et al., 2009), [43] (Lechner et al., 2011), [44] (Johannesson et al., 2003), [45] (Jiang and Yu, 2009), [46] (Sakuma et al., 2002), [47] (Lee et al., 2010), [48] (Kim et al., 2011), [49] (Tang et al., 2013), [50] (van Hengel et al., 2004), [51] (Soderman et al., 1996), [52] (Valdes et al., 2012), [53] (Chinnusamy et al., 2003), [54] (Yamamoto et al., 2009), [55] (Brocard-Gifford et al., 2003), [56] (Reyes and Chua, 2007), [57] (Tran et al., 2004), [58] (Yanhui et al., 2006), [59] (Li et al., 2006), [60] (Kang and Singh, 2000), [61] (Kang et al., 2003), [62] (Johnson et al., 2003), [63] (Zander et al., 2010), [64] (Fonseca et al., 2010), [65] (Thibaud-Nissen et al., 2006), [66] (Choi et al., 2010), [67] (Zhou et al., 2000), [68] (Kang and Klessig, 2005), [69] (Duan et al., 2007), [70] (Robatzek and Somssich, 2001), [71] (Yu et al., 2001), [72] (Lai et al., 2008), [73] (Chen et al., 2010), [74] (Hu et al., 2013), [75] (Chen et al., 2013), [76] (Zhang et al., 2007), [77] (Scarpeci et al., 2013), [78] (Li et al., 2013).

\begin{tabular}{|c|c|c|c|c|c|c|c|c|c|c|c|c|c|c|c|c|c|c|c|}
\hline \multirow{3}{*}{ TF } & \multirow{3}{*}{ Acc. No. } & \multicolumn{14}{|c|}{ Promoters of } & \multirow{3}{*}{ TF Family } & \multirow{3}{*}{ Regulation } & \multirow{3}{*}{ GO/Functional Description } & \multirow{3}{*}{ Reference } \\
\hline & & \multicolumn{6}{|c|}{ AGO } & & & & \multicolumn{2}{|c|}{ RDR } & \multicolumn{3}{|c|}{ DCL } & & & & \\
\hline & & 1 & 2 & 3 & 4 & 5 & 6 & 7 & 9 & 101 & 2 & 6 & 1 & 23 & 4 & & & & \\
\hline ABI3 & AT3G24650 & - & & & & & & & - & - & & & $\bullet$ & & & B3 & ABA & ABA-activated signalling pathway - response to $\mathrm{ABA}$ & {$[29,30]$} \\
\hline ABI4 & AT2G40220 & & & & & & & & & & & & & - & & ERF & ABA & ABA-activated signalling pathway & [31-35] \\
\hline ABI5 & AT2G36270 & - & & & & & & & & - & & & & & & bZIP & ABA & ABA-activated signalling pathway - response to $\mathrm{ABA}$ & {$[29,36-40]$} \\
\hline ANAC062 & AT3G49530 & & & - & & & & & & & & & & & & NAC & ABA & $\begin{array}{l}\text { Plays a regulatory role in ABA-mediated drought-resistance. Mediates induction of } \\
\text { pathogenesis-related (PR) genes independently of salicylic signalling in response to } \\
\text { cold }\end{array}$ & {$[41,42]$} \\
\hline ATAF1 & AT1G01720 & $\bullet$ & & & & & & & & & & & & $\bullet \bullet$ & & NAC & ABA & Negative regulation of $\mathrm{ABA}$-activated signalling pathway & {$[26,27]$} \\
\hline AtHB33 & AT1G75240 & $\bullet$ & $\bullet$ & & & & & $\bullet$ & & & $\bullet$ & & & $\bullet$ & $\bullet$ & ZF-HD & ABA & $\begin{array}{l}\text { Repressed by ABA and ARF2, Regulators in the ABA signal pathway that confers } \\
\text { sensitivity to ABA in an ARF2-dependent manner. }\end{array}$ & [27] \\
\hline ATHB5 & AT5G65310 & & & & & & & & & & & • & & & & HD-ZIP & ABA & $\begin{array}{l}\text { Probable transcription factor that acts as a positive regulator of ABA-responsiveness, } \\
\text { mediating the inhibitory effect of ABA on growth during seedling establishment. } \\
\text { Binds to the DNA sequence } 5^{\prime} \text {-CAATNATTG-3'. }\end{array}$ & [27] \\
\hline AT-HSFA9 & AT5G54070 & & & & & - & & & & & & & & & & HSF & ABA & $\begin{array}{l}\text { A member of Heat Stress Transcription Factor (Hsf) family. Not responding to heat } \\
\text { stress. Is regulated by the seed-specific transcription factor ABI3. In turn, it } \\
\text { regulates other heat stress proteins including Hspl71.4-CI, Hsp17.7-CII and Hsp101 } \\
\text { during seed maturation. }\end{array}$ & [44] \\
\hline DREB19 & AT2G38340 & & $\bullet$ & & & & & & & & - & & & - & & ERF & ABA & $\begin{array}{l}\text { Induced by ABA treatment. Transcriptional activator that binds specifically to the } \\
\text { DNA sequence 5'-[AG]CCGAC-3'. Binding to the C-repeat/DRE element mediates } \\
\text { ABA-inducible transcription }\end{array}$ & [46] \\
\hline DREB2 & AT5G05410 & & - & & $\bullet$ & & & & $\bullet$ & & $\bullet$ & & $\bullet$ & $\bullet \bullet$ & & ERF & ABA & $\begin{array}{l}\text { the ABA-dependent pathway plays a positive role in the osmotic stress-responsive } \\
\text { expression of DREB2A }\end{array}$ & {$[47,48]$} \\
\hline FHY3 & AT3G22170 & & & & $\bullet$ & & & & & & & & & & & FAR1 & ABA & $\begin{array}{l}\text { FHY3 and FAR1 are positive regulators of ABA signalling and provide insight into } \\
\text { the integration of light and ABA signalling }\end{array}$ & [49] \\
\hline GL2 & AT1G79840 & & & & & & & & & & & $\bullet$ & & & & HD-ZIP & ABA & $\begin{array}{l}\text { The expression patterns of arabinogalactan-protein AtAGP30 and GLABRA2 reveal } \\
\text { a role for ABA in the early stages of root epidermal patterning. }\end{array}$ & [50] \\
\hline HB-7 & AT5G46880 & & & & & - & & & & & & $\bullet$ & & & & HD-ZIP & ABA & NDUCTION: By water deficit, by ABA and by salt stress & {$[51,52]$} \\
\hline
\end{tabular}


Table 1. Cont.

\begin{tabular}{|c|c|c|c|c|c|c|c|c|c|c|c|c|c|c|c|c|}
\hline \multirow{3}{*}{ TF } & \multirow{3}{*}{ Acc. No. } & \multicolumn{11}{|c|}{ Promoters of } & \multirow{3}{*}{ TF Family } & \multirow{3}{*}{ Regulation } & \multirow{3}{*}{ GO/Functional Description } & \multirow{3}{*}{ Reference } \\
\hline & & \multicolumn{4}{|c|}{ AGO } & & & \multicolumn{2}{|c|}{ RDR } & \multicolumn{3}{|c|}{ DCL } & & & & \\
\hline & & 1 & 23 & 4 & $\begin{array}{ll}5 & 6 \\
\end{array}$ & 7 & $\begin{array}{ll}9 & 10 \\
\end{array}$ & $\begin{array}{lll}10 & 1 & 2\end{array}$ & 26 & $\begin{array}{ll}1 & 2 \\
\end{array}$ & 3 & 4 & & & & \\
\hline ICE1 & AT3G26744 & & $\bullet$ & $\bullet$ & & $\bullet$ & - $\bullet$ & - & $\bullet$ & $\bullet \bullet$ & $\bullet$ & - & bHLH & ABA & INDUCTION: By high-salt stress, cold stress and ABA treatment. & [53] \\
\hline LEC1 & AT1G21970 & & & & $\bullet$ & & & & - & & & & NF-YB & $\mathrm{ABA}$ & ABA-activated signalling pathway & {$[55,57]$} \\
\hline MYB33 & AT5G06100 & & & - & & - & & & & $\bullet$ & & & MYB & ABA & positive regulation of ABA-activated signalling pathway & [56] \\
\hline NAC3 & AT3G15500 & & $\bullet$ & & & & & & & & & & NAC & $\mathrm{ABA}$ & $\begin{array}{l}\text { Strongly induced by high salinity. Slightly up-regulated by drought, ABA and } \\
\text { jasmonic acid. Not induced by cold treatment. }\end{array}$ & [57] \\
\hline WRKY2 & AT5G56270 & & & & & & & & - & & & & WRKY & $\mathrm{ABA}$ & $\begin{array}{l}\text { Transcription factor. Regulates WOX8 and WOX9 expression and basal cell division } \\
\text { patterns during early embryogenesis. Interacts specifically with the W box } \\
\left.\text { (5'-(T)TGACCTT-3 } 3^{\prime}\right) \text {, a frequently occurring elicitor-responsive cis-acting element. } \\
\text { Required to repolarize the zygote from a transient symmetric state }\end{array}$ & [45] \\
\hline ATHB16 & AT4G40060 & & & & & & & $\bullet$ & & & & & HD-ZIP & $\mathrm{ABA}$ & $\begin{array}{l}\text { MATH/BTB CRL3 receptors target the homeodomain-leucine zipper ATHB6 to } \\
\text { modulate ABA signalling. }\end{array}$ & [43] \\
\hline MYB59 & AT5G59780 & & & & & & & • & & & & & MYB & SA & Isoform MYB59-1 is induced by JA, SA, gibberellic acid, and ethylene & [58,59] \\
\hline MYB65 & AT3G11440 & & & & & - & & & & & & & MYB & SA & response to SA & [58] \\
\hline OBP1 & AT3G50410 & $\bullet$ & $\bullet$ & $\bullet$ & & $\bullet$ & - $\bullet$ & • & $\bullet$ & $\bullet \bullet$ & $\bullet$ & & bZIP & SA & Induced by SA, Constitutively expressed in the whole plant & [59] \\
\hline TGA3 & AT1G22070 & & & & $\bullet$ & & & & & & & & bZIP & SA & systemic acquired resistance, SA mediated signalling pathway & {$[62,65-68]$} \\
\hline TGA4 & AT5G10030 & - & & - & - & - & - $\bullet$ & • & - & $\bullet \bullet$ & - • & - & bZIP & SA & $\begin{array}{l}\text { Binding to the as-1-like cis elements mediate auxin- and SA-inducible transcription. } \\
\text { May be involved in the induction of the systemic acquired resistance (SAR) via its } \\
\text { interaction with NPR1. }\end{array}$ & {$[60,67]$} \\
\hline WRKY1 & AT2G04880 & $\bullet$ & $\bullet$ & & & & - & & • & & & - & WRKY & SA & SA-mediated signalling pathway & [69] \\
\hline WRKY15 & AT2G23320 & & & & & & & & & & & - & WRKY & SA & Induced by SA & [71] \\
\hline WRKY21 & AT2G30590 & & & & & & $\bullet$ & • & & - & & - & WRKY & SA & Induced by SA & [71] \\
\hline WRKY26 & AT5G07100 & & & & & & & $\bullet$ & & & & & WRKY & SA & Induced by SA & {$[71,76]$} \\
\hline WRKY3 & AT2G03340 & $\bullet$ & - & & - & & - • & - & - & - $\bullet$ & b & - & WRKY & SA & induced by SA and during leaf senescence & {$[70,71]$} \\
\hline WRKY30 & AT5G24110 & & $\bullet$ & & & & & & & & & & WRKY & SA & response to SA & [77] \\
\hline WRKY4 & AT1G13960 & & & & & & - $\bullet$ & & & $\bullet \bullet$ & $\bullet$ & $\bullet$ & WRKY & SA & INDUCTION: By biotic and abiotic stresses such as pathogen infection, $\mathrm{SA}, \mathrm{JA}, \mathrm{ACC}$ & [72] \\
\hline WRKY54 & AT2G40750 & & & & & & & • & & & & & WRKY & SA & $\begin{array}{l}\text { WRKY70 and WRKY54 co-operate as negative regulators of stomatal closure and, } \\
\text { consequently, osmotic stress tolerance in Arabidopsis, suggesting that they have an } \\
\text { important role, not only in plant defence, but also in abiotic stress signalling. } \\
\text { WRKY70 and WRKY54 are positive regulators of plant defence, and co-operate as } \\
\text { negative regulators of SA biosynthesis and senescence. }\end{array}$ & [78] \\
\hline ОВР3 & AT3G55370 & & & & & & - & & & & & & bZIP & SA-JA & Induced by SA, Repressed by JA & {$[60,61]$} \\
\hline TGA2 & AT5G06950 & $\bullet$ & $\bullet$ & & $\bullet$ & $\bullet$ & - • & - & $\bullet$ & $\bullet \bullet$ & $\bullet$ & $\bullet$ & bZIP & $\mathrm{SA}-\mathrm{JA} / \mathrm{Et}$ & $\begin{array}{l}\text { Required to induce the systemic acquired resistance (SAR) via the regulation of } \\
\text { pathogenesis-related genes expression }\end{array}$ & [62-65] \\
\hline TGA5 & AT5G06960 & & $\bullet$ & - & & $\bullet$ & - • & - & $\bullet$ & $\bullet$ & $\bullet$ & $\bullet$ & bZIP & $\mathrm{SA}-\mathrm{JA} / \mathrm{Et}$ & $\begin{array}{l}\text { May be involved in the induction of the systemic acquired resistance (SAR) via its } \\
\text { interaction with NPR1. }\end{array}$ & {$[63,67,68]$} \\
\hline TGA6 & АТЗG12250 & $\bullet$ & $\bullet$ & & $\bullet$ & $\bullet$ & - $\bullet$ & - & $\bullet$ & - $\bullet$ & $\bullet$ & $\bullet$ & bZIP & SA- JA/Et & $\begin{array}{l}\text { May be involved in the induction of the systemic acquired resistance (SAR) via its } \\
\text { interaction with NPR1. }\end{array}$ & {$[63,67,68]$} \\
\hline WRKY8 & AT5G46350 & & - & & & & & & & & & & WRKY & $\mathrm{SA} / \mathrm{ABA}$ & $\begin{array}{l}\text { Induced by wounding, } \mathrm{ABA}, \mathrm{SA}, \mathrm{H} 2 \mathrm{O} 2 \text { and infection with P.syringae pv. tomato } \\
\text { DC3000 and B.cinerea }\end{array}$ & {$[73,74,76]$} \\
\hline
\end{tabular}




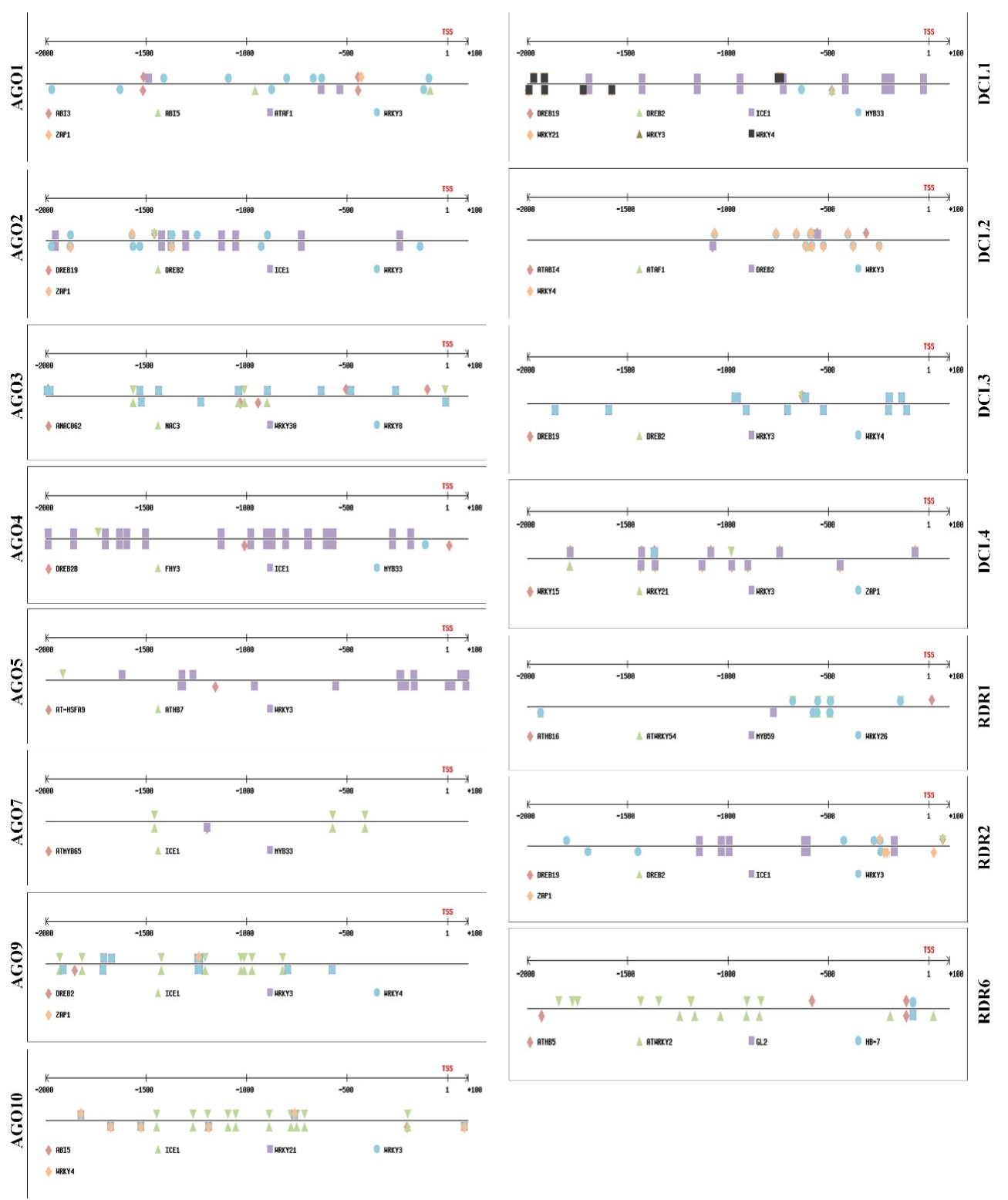

Figure 1. Transcription factor (TF) binding sites of ABA- and SA-related TFs in the promoters of RNA silencing genes: Binding sites of ABA- and SA-regulated TFs on the promoters of RNA silencing genes ( $A G O, D C L$, and RDR gene families). Promoter regions $2000 \mathrm{bp}$ upstream of the transcription start site (TSS) were subjected to promoter analyses using the Plant Promoter Analysis Navigator in PlantPan 2.0. The TFs and their binding sites (cis-regulatory elements) were visualized using PlantPan 2.0.

\subsection{ABA and SA Exert Similar Effects on Expression of Several Genes in the RNA Silencing Pathway}

To examine the effects of $\mathrm{ABA}$ and SA on the expression of $A G O, D C L$, and RDR genes, we treated the seedlings of the WT, the SA mutant sid2-1, the ABA mutant aao3, and the ABA-SA double mutant sid2-1:aao3 with ABA, SA, or mock. Seedlings were collected two days after hormone treatment for analysis of gene expression.

Interestingly, SA exhibited negative effects on AGO1 expression as SA treatment decreased AGO1, while SA mutants increased AGO1 expression (Figure 2A). In contrast, ABA treatment enhanced AGO1 expression in all lines, especially in sid2-1 in which ABA content is higher than WT [7] (Figure 2A). In line with $\mathrm{ABA}$ effects, impairment of $\mathrm{ABA}$ in the single mutant reduced AGO1 expression (Figure 2A). 

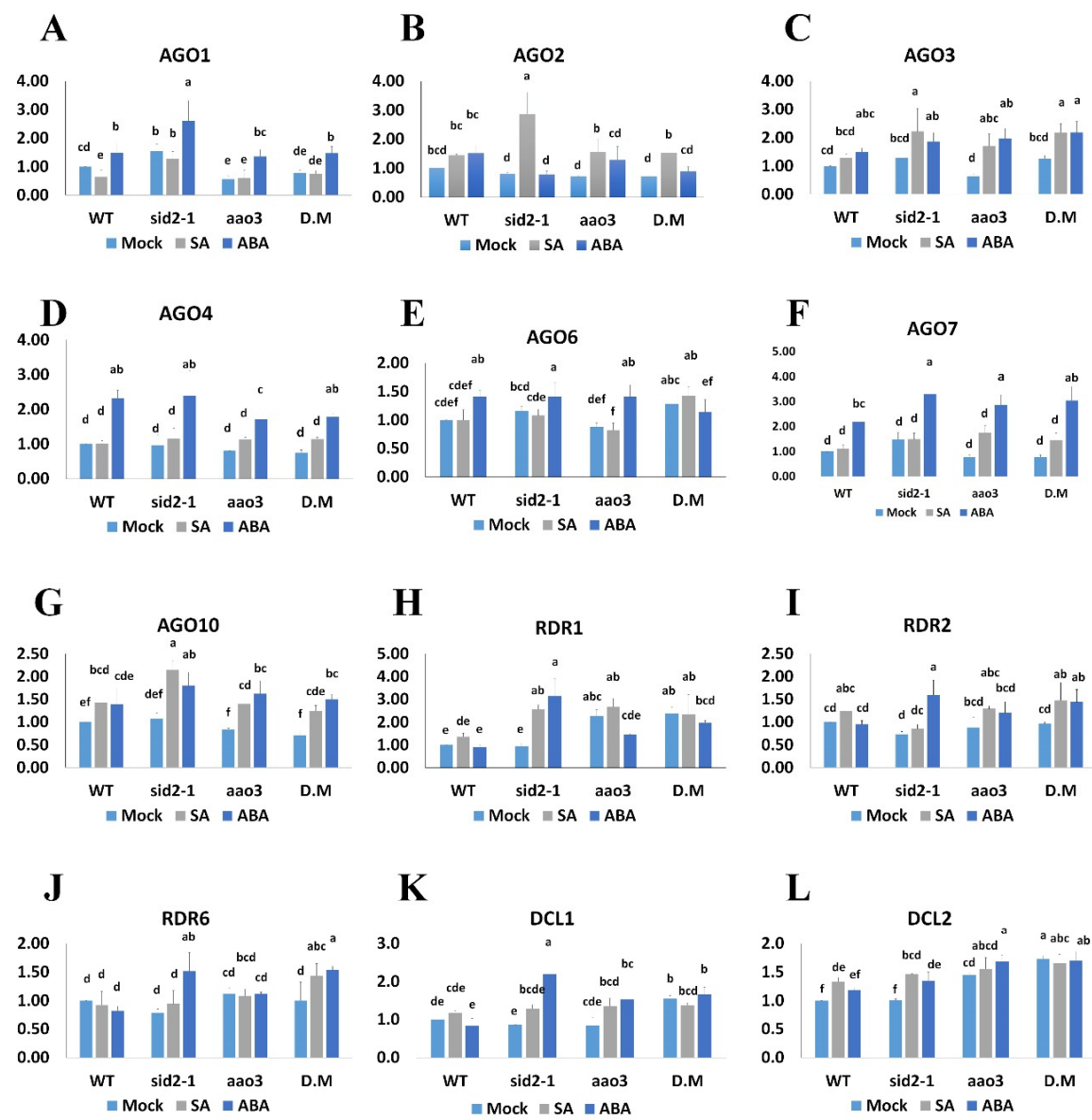

\section{K}

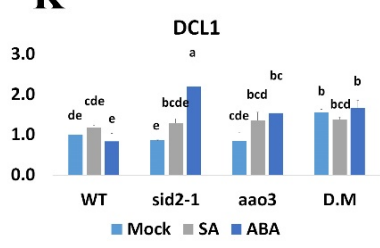

L
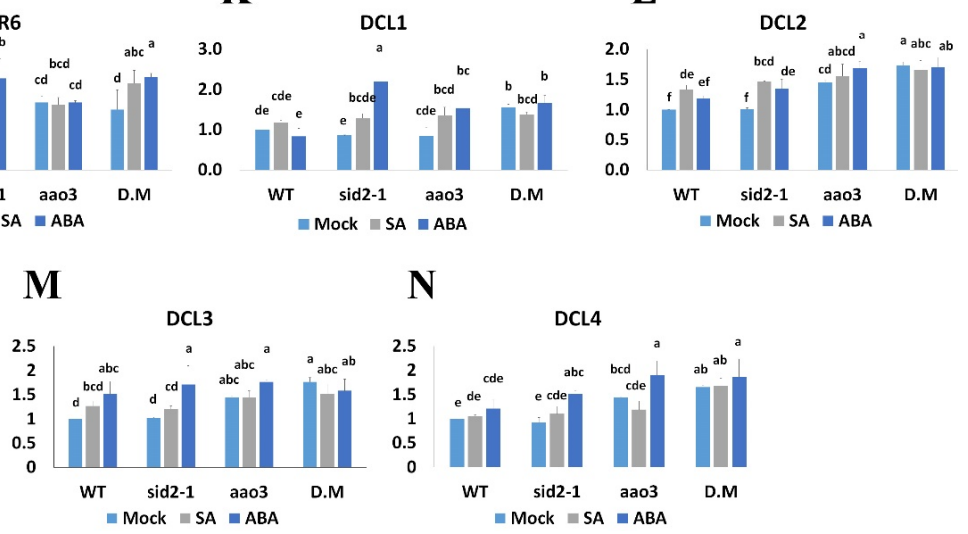

Figure 2. Effects of $\mathrm{ABA}$ and $\mathrm{SA}$ treatment on the relative expression (as determined by RT-qPCR) of (A) AGO1, (B) AGO2, (C) AGO3, (D) AGO4, (E) AGO6, (F) AGO7, (G) AGO10, (H) RDR1, (I) RDR2, (J) RDR6, (K) DCL1, (L) DCL2, (M) DCL3, and (N) DCL4 in seedlings of the Arabidopsis thaliana wild type (WT), the SA mutant sid2-1, the ABA mutant aao3, and their double mutant (D.M) sid2-1:aao3. Six-day-old seedlings were treated with SA $(50 \mu \mathrm{M}), \mathrm{ABA}(10 \mu \mathrm{M})$, or mock $(0.1 \% \mathrm{EtOH})$; expression was determined by RT-qPCR 2 days later. Values are means + SD of three biological replicates, each carried out with three technical replicates. Analyses of variance (ANOVAs) were conducted to determine significant differences $(p<0.05)$; when ANOVAs were significant, the means for each gene were compared with a Duncan's post hoc test; means that share a lowercase letter are not statistically different, while different letters denote for statistical differences at least $95 \%$ confidence.

Both SA treatment and ABA treatment caused marginal increases in the expression of AGO2 in WT seedlings, but ABA treatment failed to increase AGO2 expression in SA mutants (sid2-1 or sid2-1:aao3) (Figure 2B). In contrast, SA treatment increased $A G O 2$ expression in both ABA and SA mutants, as well as in their double mutant. Because the impairment of SA synthesis diminished the effect of ABA, we inferred that $\mathrm{ABA}$ acts upstream of $\mathrm{SA}$ in inducing $A G O 2$ expression. In the mock-treated lines, $A G O 2$ expression was marginally lower in the single and double mutants than in the WT, which confirmed that both hormones enhance AGO2 expression (Figure 2B). Similarly, AGO3 and AGO10 showed marginal increases following ABA or SA treatment of WT plants. Nevertheless, the effect 
of both hormones was more pronounced on single and double mutants than on the WT, leading to significant differences in the expression of both genes (Figure 2C,G).

ABA treatment increased the expression of $A G O 4, A G O 6$, and $A G O 7$ in all lines except for expression of $A G O 6$ in the double mutant (Figure 2D-F). Expression of $A G O 4, A G O 6$, and $A G O 7$ was not altered by SA treatment or in the sid2-1 mutant (Figure 2D-F). Therefore, we inferred that both hormones have similar positive effects on the expression of $A G O 2,-3,-4$, and -10, while SA exerts a negative effect on the expression of $A G O 1$.

In the RDR family, SA treatment of the WT seedlings marginally increased the expression of RDR1 (Figure $2 \mathrm{H}$ ) but did not affect the expression of RDR2 or RDR6 (Figure 2I,J). ABA treatment increased the expression of $R D R 1, R D R 2$, and $R D R 6$ only in sid2-1 (Figure $2 \mathrm{H}-\mathrm{J}$ ).

The ability of ABA to induce $R D R 1, R D R 2$, and $R D R 6$ expression when SA synthesis was impaired indicated that the antagonism between $\mathrm{ABA}$ and $\mathrm{SA}$ influences the expression of these genes.

In WT plants, SA treatment increased DCL2 expression and marginally induced DCL3 and 4 (Figure 2K-N), while ABA treatment of WT plants increased DCL3 expression and marginally increased DCL4 expression (Figure 2M,N). In the mock-treated aao3 mutant, the expression of DCL2, -3 , and -4 was higher than in WT mock. However, SA or ABA treatment often increased the expression of these genes in single mutants, notably in sid2-1 treated with $\mathrm{ABA}$, which indicates that such genes are more sensitive to ABA than to SA. Hormone effects were absent in the double mutant, perhaps because the $D C L$ expression levels were already substantially higher in the mock-treated double mutant than in the mock-treated WT. These results indicate that DCL genes might be regulated in parallel by several factors or hormones that exert clear effects under low ABA or SA conditions, suggesting that such factors/hormones might be antagonistic to both ABA and SA.

\subsection{Susceptibility to BaMV Is Not Greater in the ABA/SA Double Mutant Than in the Single Mutants}

Finally, we tested the effect of impaired SA and ABA synthesis on plant tolerance to BaMV infection. Using AGROBEST methodology (Agrobacterium-mediated transformation of BaMV infectious clone (pKB)) [3,79], WT, the SA mutant sid2-1, the ABA mutant aao3, and the SA-ABA double mutant sid2-1:aao3 were transfected with $\mathrm{pKB}$. As expected, BaMV CP levels were higher in the single mutants than in the WT (Figure 3). The BaMV CP level was not higher, however, in the double mutant than in the single mutants (Figure 3). These results indicate that the affected defense mechanism in the single mutants might be regulated in parallel by SA and ABA (Figure 3).

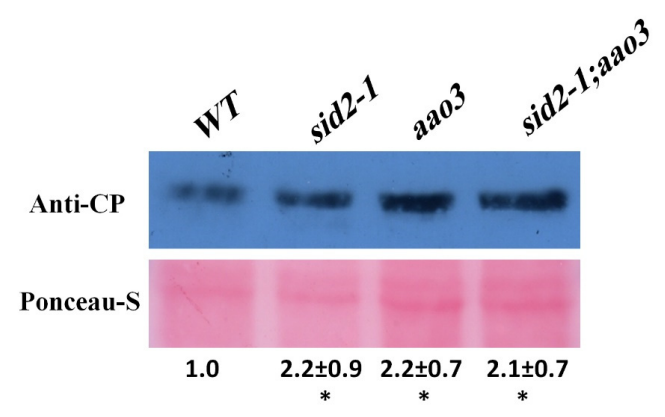

Figure 3. The susceptibility of wild type (WT) and ABA and SA mutant seedlings to BaMV. Six-day-old seedlings of the WT, sid2-1, aao3, and sid2-1:aao3 were infected with a BaMV infectious clone (pKB) using Agrobacterium-mediated transformation (AGROBEST method). Total proteins were extracted 4 days later, and BaMV coat protein was quantified by Western blot analysis as indicated in the figure. The experiment was carried out in 3 biological replicates with similar results (Figure S2). Band densities (anti-CP and RuBisCO from Ponceau-S staining) were measured with Image J software, and the CP level in each line was normalized to the corresponding Rubisco band. Values are means \pm SD of three biological replicates. An asterisk indicates a significant increase relative to the WT (which was set at $1.0)$ according to a one-sided Student's $t$-test $(p<0.05)$. 


\section{Discussion}

The coexpression analyses conducted using PlantPan 2.0 provided a list of TFs that might be coexpressed with the RNA silencing-related genes of interest in this study. These TFs had been experimentally verified to be induced by SA and ABA treatments based on publicly available RNAseq data that PlantPan 2.0 and ExPath 2.0 collaboratively use $[20,25]$. The coexpression analyses showed that the selected TFs can be coexpressed with RNA silencing genes in response to various hormone treatments (Table 1). TFBSs in the promoter regions of the RNA silencing genes were then identified based on the experimentally verified cis-elements compiled in PlantPan 2.0.

Both ABA and SA have been reported to greatly affect the resistance to several viruses $[10,11]$, including BaMV, PVX, and soybean mosaic virus in response to ABA [3,12]. With bamboo mosaic virus as an example, the results presented here suggest that certain ABA- or SA-related TFs regulate the expression of the RNA silencing genes, which may explain how both hormones influence resistance to viruses through the RNA silencing pathway.

In response to ABA, several TFs are coexpressed and act hierarchically; their dynamic binding to the promoters of target genes defines plant responses to the stress [80]. Song et al. (2016) found that highly upregulated genes are often targeted by several TFs through top-up building, while downregulated genes are associated either with static binding by TFs or with downregulated TF binding. It follows that the hierarchical activity of the coexpressed ABA-related TFs identified in Table 1 can promote coordinated regulation of the ABA-regulated RNA silencing genes. Such dynamic binding activity can also be expected for the SA-related TFs on their target genes.

The RNA silencing pathways are partially controlled by several hormones/networks in order to fine-tune plant responses to various biotic/abiotic stresses. Hormone pathways such as those for $\mathrm{SA}, \mathrm{ABA}$ auxin, and ethylene were previously reported to partially regulate a few components in the RNA silencing pathways $[3,13,14,16,81,82]$. Although antagonism is the only previously reported relationship that directly governs the interactive effects of the SA and ABA pathways, the current study shows that their regulatory effects on the expression of the RNA silencing genes are similar for some genes, antagonistic for others, and hierarchical for AGO2 (Figure 2). The expression of AGO1 is probably a subject of such antagonism because the SA biosynthesis gene ICS1 is highly upregulated in the aao3 mutant [7], which might explain the downregulation of $A G O 1$ in aao3. Antagonism between $\mathrm{ABA}$ and $\mathrm{SA}$ was also observed for their regulation of the RDR genes in that ABA enhanced their expression only in SA mutants (Figure 2H-J).

Both hormones had marginal but positive effects on the expression of AGO2, AGO3, AGO10, $D C L 2, D C L 3$, and DCL4 in WT seedlings (Figure 2). However, such effects become more pronounced when a mutant of either pathway was treated with the hormone of the other pathway; this was the case for most of these genes when sid2-1 was treated with ABA, and for AGO2, AGO3, and AGO10 when $a a 03$ was treated with SA. The inability of ABA to induce $A G O 2$ in the SA mutant indicates that ABA acts upstream of SA in inducing $A G O 2$ and represents a rare example of SA-dependency for an ABA-regulated gene (Figure $2 \mathrm{~B}$ ). It was previously reported that $\mathrm{SA}$ treatment only slightly increased AGO2 expression in WT plants, but substantially increased AGO2 expression in 2b-transgenic lines (cucumber mosaic virus $2 \mathrm{~b}$ protein) [83]. The existence of TFs that are positively regulated by SA and that bind to some $A G O$ promoters suggests that SA may enhance the expression of $A G O 4, A G O 6$, and $A G O 7$, but the expression of such genes is probably spatiotemporal regulated. In previous studies, SA increased AGO1 expression during leaf senescence [70,84], but SA reduced AGO1 expression in seedlings in the current study (Figure 2). Thus, the effect of SA on AGO1 can be positive or negative depending on plant age or tissue (Figure 1). The regulatory effect of ABA on some genes may also be age-dependent [85]. ABA treatment did not increase AGO7 expression in 35-day-old $A$. thaliana plants in our previous study [3], but did so in the 8-day-old seedlings of the current study (Figure 2F). This suggests that the effect of ABA could be spatiotemporal and/or indirect.

None of the mutants tested, including the double mutant, showed a substantial decrease in the expression of any of the genes in the seedling stage (eight days old) (Figure 3). This observation 
supports the notion that the RNA silencing pathway might be controlled by several networks involved in several cellular processes, such that plants cannot afford a complete shutdown of this pathway. As a consequence, the expression levels of many of those genes are evidently maintained at some minimum level by multiple factors.

The expression of $A G O 1,2,3$, and 10 was marginally downregulated in the aao3 and sid2-1 mutants (Figure 2A,B,C,G). Except for $A G O 10$, mutants of all of these $A G O$ s affect the susceptibility of $A$. thaliana to BaMV [3]. None of these $A G O$ s showed enhanced downregulation in the double mutant, which suggests that there are other complementary factors/hormones that help maintain a minimum level of AGO gene expression in the absence of ABA or SA. These other factors could include the antagonistic hormones jasmonic acid, ethylene, or auxins [86], which may regulate the expression of some RNA silencing genes through their related TFs (Table S1). In addition, the enhanced susceptibility to BaMV in the single or double mutants at the seedling stage suggests that other defense mechanisms are also influenced by the impairment of ABA or SA pathways. Callose deposition, which limits virus spread, is decreased when ABA or SA levels are low [11]. ROS accumulation, which also contributes to basal immunity against several viruses, is increased in the sid2-1 mutant, but ROS levels were lower in the ABA signaling mutant abi4-1 than in the WT $[87,88]$. The overall outcome of defense against BaMV in A. thaliana seedlings appears to be equal among single and double mutants.

In conclusion, ABA and SA enhance plant defense to RNA viruses largely via the antiviral RNA silencing pathway, i.e., both hormones increase the expression of those genes in the RNA silencing pathway that are required for Arabidopsis resistance to BaMV. The coexpression analyses identified several ABA and SA TFs that may regulate the expression of those genes. Other candidate TFs regulated by other hormones such as ethylene or jasmonic acid also suggest that the RNA silencing pathway is a hub tuned by hormones in response internal or external stimuli. The effect of hormones on RNA silencing may not be equal or similar; for example, the expression of several AGOs was influenced more by ABA than by SA. The effects of ABA and SA on the RNA silencing genes depend on the individual gene: in some cases, the effects are similar, and in other cases they are redundant, hierarchical, or antagonistic. It also seems that the effect of hormones on the RNA silencing pathway is influenced by plant age and tissue. Additional research is therefore needed to understand how hormones regulate the RNA silencing pathway during different stages of plant growth and in response to different stresses.

\section{Materials and Methods}

\subsection{Coexpression and Promoter Analyses}

PlantPan 2.0 was used to identify TFs that are coexpressed with genes in the AGO, DCL, and RDR families [20]. By selecting hormone treatments and/or environmental stress conditions, we obtained lists of TFs that are coexpressed with the queried gene as indicated by a Pearson correlation coefficient with a $p$-value $>0.8$ (Table S1). To obtain a shortlist of TFs that are regulated only by SA or ABA, GO and functional descriptions of these TFs were queried manually in the Plant Transcription Factor Database v4.0 http://planttfdb.cbi.pku.edu.cn/ [89]. All TFs regulated by ABA or SA along with the promoters that the TFs probably bind to are listed in Table 1.

Regions $2000 \mathrm{bp}$ upstream of the transcription start sites (TSSs) containing the promoters of $A G O$, $D C L$, and RDR family genes were subjected to promoter analyses using the Plant Promoter Analysis Navigator in PlantPan 2.0 [20]. The TFs and their binding sites within the promoter regions were visualized using PlantPan 2.0.

\subsection{Plant Materials}

The following A. thalianalines were used; wild type (Col-0), SA-biosynthesis mutant (sid2-1), ABA-biosynthesis mutant (aao3), and their double mutant (sid2-1:aao3). Seeds of these lines were germinated and grown in liquid MS medium at $20^{\circ} \mathrm{C}$ under a $16 / 8 \mathrm{~h}$ photoperiod in 6 -well plates until they were 6 days old, at which time hormone treatments were applied. 


\subsection{Hormone Treatments}

When seedlings were 6 days old, the liquid MS medium was replaced with fresh MS containing ABA $(10 \mu \mathrm{M})$, SA $(50 \mu \mathrm{M})$, or mock $\left(0.5 \% \mathrm{EtOH}\right.$ in $\left.\mathrm{ddH}_{2} \mathrm{O}\right)$. Two days after treatment, 10 seedlings from each line (WT, sid2-1, aao3, and sid2-1:aao3) were collected for RNA extraction and cDNA synthesis.

\subsection{RNA Extraction and Real-Time Quantitative PCR (RT-qPCR)}

Total RNA was extracted using TRIzol following the manufacturer's instructions. First-strand cDNA was generated with the Superscript III kit (Invitrogen), and RT-qPCR was carried out with SYBR green (Roche) using $\Delta \Delta C_{t}$ methodology. Actin was used as a reference gene as described previously [3,90]. The RT-qPCR primers used in this study are listed in Table S3. One-sided Student's $t$-tests $(p<0.05)$ were used to determine whether the expression level of each gene in each line was upregulated or downregulated relative to the mock-treated WT.

\subsection{Protein Analyses}

Six-day-old seedlings of the WT, sid2-1, aao3, and sid2-1:aao3 were inoculated with the pKB clone of BaMV [91] using the AGROBEST method as described previously [3,79]. Total proteins were extracted 4 days after inoculation as described previously [3]. BaMV coat protein (CP) was detected as described previously $[23,90]$. The experiment was carried out in 3 biological replicates with similar results (Figure S2).

\subsection{Statistical Analysis}

Treatments were applied to seedlings arranged in completely randomized blocks. RTqPCR data (means $\pm \mathrm{SD}$ ) were subjected to two-way analyses of variance (ANOVAs) to compare the effects of hormone treatments and plant lines on the expression of each gene. When an ANOVA was significant $(p<0.05)$, means were compared with a Duncan's post hoc test. Different letters denote for statistical differences at least 95\% confidence. The CoStat package, version 6.451, was used for statistical analysis.

Supplementary Materials: Supplementary materials can be found at http://www.mdpi.com/1422-0067/20/10/ 2538/s1. Figure S1. Transcription factor binding sites of TFs on promoters with abundant cis-regulatory elements: The TFs HB33, ICE1, OBP1 (TGA1), TGA2, TGA3, TGA4, TGA5, and TGA6 have several binding sites for the promoters of RNA silencing genes. Transcription factors TGA1 (OBP1), 2, 3, 4, 5, and 6 bind to the same TF-motif TGACG (TF_motif_seq_0271) [92-95]. PlantPan 2.0 was used for promoter analysis and TFBS visualization. Figure S2. The susceptibility of wild type (WT) and ABA and SA mutant seedlings to BaMV infection. Table S1. Lists of TFs that are coexpressed with the RNA silencing genes (AGO, DCL, and RDR gene families) in response to the indicated hormone treatments and environmental stresses. TFs were included if their Pearson correlation coefficients were $p$-values $>0.9$ (except that TFs for AGO5 and RDR1 were included if their correlation coefficients were $>0.6$ ). Table S2. Characteristics of the public microarray data compiled in ExPath 2.0 and used by PlantPan 2.0 for coexpression analyses. Table S3. Primers used in the study.

Author Contributions: M.A., K.-H.K., and N.-S.L. conceived the work plan, and M.A. conducted the experiments and data analysis and prepared the first draft of the manuscript, which was edited and approved by all authors.

Funding: This research was supported by the Korea Research Fellowship program funded by the Ministry of Science and ICT through the National Research Foundation of Korea (KRF grant no. 2017H1D3A1A01054585), and the Vegetable Breeding Research Center (no. 710001-3) through the Agriculture, the Food and Rural Affairs Research Center Support Program from the Ministry of Agriculture, Food and Rural Affairs, Republic of Korea.

Acknowledgments: We thank Marta de Torres (University of Exeter, UK) for providing the mutant lines. We also thank the Sequencing Core Laboratory and Pai Hsuan at the Institute of Plant and Microbial Biology, Academia Sinica, Taiwan, and the following individuals for technical assistance: Chi-Nga Chow and Wen-Chi Chang (National Cheng-Kung University, Taiwan), and Lia Spencer (Carleton College, USA).

Conflicts of Interest: The authors declare no conflicts of interest. 


\section{References}

1. Sah, S.K.; Reddy, K.R.; Li, J. Abscisic Acid and Abiotic Stress Tolerance in Crop Plants. Front. Plant Sci. 2016, 7, 571. [CrossRef]

2. Ton, J.; Flors, V.; Mauch-Mani, B. The multifaceted role of ABA in disease resistance. Trends Plant Sci. 2009, 14, 310-317. [CrossRef]

3. Alazem, M.; He, M.H.; Moffett, P.; Lin, N.S. Abscisic Acid Induces Resistance against Bamboo Mosaic Virus through Argonaute2 and 3. Plant Physiol. 2017, 174, 339-355. [CrossRef] [PubMed]

4. Klessig, D.F.; Choi, H.W.; Dempsey, D.A. Systemic Acquired Resistance and Salicylic Acid: Past, Present, and Future. Mol. Plant Microbe Interact 2018, MPMI03180067CR. [CrossRef] [PubMed]

5. Yasuda, M.; Ishikawa, A.; Jikumaru, Y.; Seki, M.; Umezawa, T.; Asami, T.; Maruyama-Nakashita, A.; Kudo, T.; Shinozaki, K.; Yoshida, S.; Nakashita, H. Antagonistic interaction between systemic acquired resistance and the abscisic acid-mediated abiotic stress response in Arabidopsis. Plant Cell 2008, 20, 1678-1692. [CrossRef]

6. Fan, J.; Hill, L.; Crooks, C.; Doerner, P.; Lamb, C. Abscisic Acid Has a Key Role in Modulating Diverse Plant-Pathogen Interactions. Plant Physiol. 2009, 150, 1750-1761. [CrossRef] [PubMed]

7. Zabala, M.D.; Bennett, M.H.; Truman, W.H.; Grant, M.R. Antagonism between salicylic and abscisic acid reflects early host-pathogen conflict and moulds plant defence responses. Plant J. 2009, 59, 375-386. [CrossRef] [PubMed]

8. Denance, N.; Sanchez-Vallet, A.; Goffner, D.; Molina, A. Disease resistance or growth: The role of plant hormones in balancing immune responses and fitness costs. Front. Plant Sci. 2013, 4, 155. [CrossRef]

9. Prodhan, M.Y.; Munemasa, S.; Nahar, M.N.E.N.; Nakamura, Y.; Murata, Y. Guard Cell Salicylic Acid Signaling Is Integrated into Abscisic Acid Signaling via the $\mathrm{Ca}^{2+} / \mathrm{CPK}-$ Dependent Pathway. Plant Physiol. 2018, 178, 441-450. [CrossRef]

10. Alazem, M.; Lin, N.S. Roles of plant hormones in the regulation of host-virus interactions. Mol. Plant Pathol. 2015, 16, 529-540. [CrossRef]

11. Alazem, M.; Lin, N.S. Antiviral Roles of Abscisic Acid in Plants. Front. Plant Sci. 2017, 8, 1760. [CrossRef]

12. Alazem, M.; Tseng, K.C.; Chang, W.C.; Seo, J.K.; Kim, K.H. Elements Involved in the Rsv3-Mediated Extreme Resistance against an Avirulent Strain of Soybean Mosaic Virus. Viruses 2018, 10, 11. [CrossRef] [PubMed]

13. Alamillo, J.M.; Saenz, P.; Garcia, J.A. Salicylic acid-mediated and RNA-silencing defense mechanisms cooperate in the restriction of systemic spread of plum pox virus in tobacco. Plant J. 2006, 48, $217-227$. [CrossRef] [PubMed]

14. Li, W.; Cui, X.; Meng, Z.; Huang, X.; Xie, Q.; Wu, H.; Jin, H.; Zhang, D.; Liang, W. Transcriptional regulation of Arabidopsis MIR168a and argonaute1 homeostasis in abscisic acid and abiotic stress responses. Plant Physiol. 2012, 158, 1279-1292. [CrossRef] [PubMed]

15. Jaubert, M.; Bhattacharjee, S.; Mello, A.F.; Perry, K.L.; Moffett, P. ARGONAUTE2 mediates RNA-silencing antiviral defenses against Potato virus X in Arabidopsis. Plant Physiol. 2011, 156, 1556-1564. [CrossRef] [PubMed]

16. Hunter, L.J.; Westwood, J.H.; Heath, G.; Macaulay, K.; Smith, A.G.; Macfarlane, S.A.; Palukaitis, P.; Carr, J.P. Regulation of RNA-dependent RNA polymerase 1 and isochorismate synthase gene expression in Arabidopsis. PLoS ONE 2013, 8, e66530. [CrossRef] [PubMed]

17. Lee, W.S.; Fu, S.F.; Li, Z.; Murphy, A.M.; Dobson, E.A.; Garland, L.; Chaluvadi, S.R.; Lewsey, M.G.; Nelson, R.S.; Carr, J.P. Salicylic acid treatment and expression of an RNA-dependent RNA polymerase 1 transgene inhibit lethal symptoms and meristem invasion during tobacco mosaic virus infection in Nicotiana benthamiana. BMC Plant Biol. 2016, 16, 15. [CrossRef]

18. Lee, C.H.; Carroll, B.J. Evolution and Diversification of Small RNA Pathways in Flowering Plants. Plant Cell Physiol. 2018, 59, 2169-2187. [CrossRef] [PubMed]

19. Csorba, T.; Kontra, L.; Burgyan, J. viral silencing suppressors: Tools forged to fine-tune host-pathogen coexistence. Virology 2015, 479-480, 85-103. [CrossRef]

20. Chow, C.N.; Zheng, H.Q.; Wu, N.Y.; Chien, C.H.; Huang, H.D.; Lee, T.Y.; Chiang-Hsieh, Y.F.; Hou, P.F.; Yang, T.Y.; Chang, W.C. PlantPAN 2.0: An update of plant promoter analysis navigator for reconstructing transcriptional regulatory networks in plants. Nucleic Acids Res. 2016, 44, D1154-D1160. [CrossRef]

21. Hsu, Y.H.; Tsai, C.H.; Lin, N.S. Editorial: Molecular Biology of Bamboo mosaic Virus-A Type Member of the Potexvirus Genus. Front. Microbiol. 2018, 9, 6. [CrossRef] [PubMed] 
22. Lin, N.S.; Lin, B.Y.; Lo, N.W.; Hu, C.C.; Chow, T.Y.; Hsu, Y.H. Nucleotide sequence of the genomic RNA of bamboo mosaic potexvirus. J. Gen. Virol. 1994, 75, 2513-2518. [CrossRef] [PubMed]

23. Lin, N.S.; Lin, F.Z.; Huang, T.Y.; Hsu, Y.H. Genome Properties of Bamboo Mosaic-Virus. Phytopathology 1992, 82, 731-734. [CrossRef]

24. DiMaio, F.; Chen, C.C.; Yu, X.; Frenz, B.; Hsu, Y.H.; Lin, N.S.; Egelman, E.H. The molecular basis for flexibility in the flexible filamentous plant viruses. Nat. Struct. Mol. Biol. 2015, 22, 642-644. [CrossRef] [PubMed]

25. Zheng, H.Q.; Wu, N.Y.; Chow, C.N.; Tseng, K.C.; Chien, C.H.; Hung, Y.C.; Li, G.Z.; Chang, W.C. EXPath tool-a system for comprehensively analyzing regulatory pathways and coexpression networks from high-throughput transcriptome data. DNA Res. 2017, 24, 371-375. [CrossRef]

26. Jensen, M.K.; Hagedorn, P.H.; de Torres-Zabala, M.; Grant, M.R.; Rung, J.H.; Collinge, D.B.; Lyngkjaer, M.F. Transcriptional regulation by an NAC (NAM-ATAF1,2-CUC2) transcription factor attenuates ABA signalling for efficient basal defence towards Blumeria graminis f. sp. hordei in Arabidopsis. Plant J. 2008, 56, 867-880. [CrossRef]

27. Wu, Y.; Deng, Z.; Lai, J.; Zhang, Y.; Yang, C.; Yin, B.; Zhao, Q.; Zhang, L.; Li, Y.; Yang, C.; Xie, Q. Dual function of Arabidopsis ATAF1 in abiotic and biotic stress responses. Cell Res. 2009, 19, 1279-1290. [CrossRef] [PubMed]

28. Wang, L.; Hua, D.; He, J.; Duan, Y.; Chen, Z.; Hong, X.; Gong, Z. Auxin Response Factor2 (ARF2) and its regulated homeodomain gene HB33 mediate abscisic acid response in Arabidopsis. PLoS Genet. 2011, 7, e1002172. [CrossRef] [PubMed]

29. Nakashima, K.; Fujita, Y.; Katsura, K.; Maruyama, K.; Narusaka, Y.; Seki, M.; Shinozaki, K.; Yamaguchi-Shinozaki, K. Transcriptional regulation of ABI3- and ABA-responsive genes including RD29B and RD29A in seeds, germinating embryos, and seedlings of Arabidopsis. Plant Mol. Biol. 2006, 60, 51-68. [CrossRef]

30. Delmas, F.; Sankaranarayanan, S.; Deb, S.; Widdup, E.; Bournonville, C.; Bollier, N.; Northey, J.G.B.; McCourt, P.; Samuel, M.A. ABI3 controls embryo degreening through Mendel's I locus. Proc. Natl. Acad. Sci. USA 2013, 110, E3888-E3894. [CrossRef]

31. Acevedo-Hernandez, G.J.; Leon, P.; Herrera-Estrella, L.R. Sugar and ABA responsiveness of a minimal RBCS light-responsive unit is mediated by direct binding of ABI4. Plant J. 2005, 43, 506-519. [CrossRef]

32. Kaliff, M.; Staal, J.; Myrenas, M.; Dixelius, C. ABA is required for Leptosphaeria maculans resistance via ABI1- and ABI4-dependent signaling. Mol. Plant Microbe Ind. 2007, 20, 335-345. [CrossRef] [PubMed]

33. Shkolnik-Inbar, D.; Bar-Zvi, D. ABI4 mediates abscisic acid and cytokinin inhibition of lateral root formation by reducing polar auxin transport in Arabidopsis. Plant Cell 2010, 22, 3560-3573. [CrossRef] [PubMed]

34. Shu, K.; Zhang, H.; Wang, S.; Chen, M.; Wu, Y.; Tang, S.; Liu, C.; Feng, Y.; Cao, X.; Xie, Q. ABI4 regulates primary seed dormancy by regulating the biogenesis of abscisic acid and gibberellins in arabidopsis. PLoS Genet. 2013, 9, e1003577. [CrossRef] [PubMed]

35. Feng, C.Z.; Chen, Y.; Wang, C.; Kong, Y.H.; Wu, W.H.; Chen, Y.F. Arabidopsis RAV1 transcription factor, phosphorylated by SnRK2 kinases, regulates the expression of ABI3, ABI4, and ABI5 during seed germination and early seedling development. Plant J. 2014, 80, 654-668. [CrossRef] [PubMed]

36. Lopez-Molina, L.; Mongrand, S.; Chua, N.H. A postgermination developmental arrest checkpoint is mediated by abscisic acid and requires the AB15 transcription factor in Arabidopsis. Proc. Natl. Acad. Sci. USA 2001, 98, 4782-4787. [CrossRef]

37. Carles, C.; Bies-Etheve, N.; Aspart, L.; Leon-Kloosterziel, K.M.; Koornneef, M.; Echeverria, M.; Delseny, M. Regulation of Arabidopsis thaliana Em genes: Role of ABI5. Plant J. 2002, 30, 373-383. [CrossRef]

38. Bensmihen, S.; Rippa, S.; Lambert, G.; Jublot, D.; Pautot, V.; Granier, F.; Giraudat, J.; Parcy, F. The homologous ABI5 and EEL transcription factors function antagonistically to fine-tune gene expression during late embryogenesis. Plant Cell 2002, 14, 1391-1403. [CrossRef]

39. Lopez-Molina, L.; Mongrand, S.; McLachlin, D.T.; Chait, B.T.; Chua, N.H. ABI5 acts downstream of ABI3 to execute an ABA-dependent growth arrest during germination. Plant J. 2002, 32, 317-328. [CrossRef]

40. Finkelstein, R.; Gampala, S.S.; Lynch, T.J.; Thomas, T.L.; Rock, C.D. Redundant and distinct functions of the ABA response loci ABA-INSENSITIVE(ABI)5 and ABRE-BINDING FACTOR (ABF)3. Plant Mol. Biol. 2005, 59, 253-267. [CrossRef] 
41. Kim, M.J.; Park, M.J.; Seo, P.J.; Song, J.S.; Kim, H.J.; Park, C.M. Controlled nuclear import of the transcription factor NTL6 reveals a cytoplasmic role of SnRK2.8 in the drought-stress response. Biochem. J. 2012, 448, 353-363. [CrossRef] [PubMed]

42. Seo, P.J.; Kim, M.J.; Park, J.Y.; Kim, S.Y.; Jeon, J.; Lee, Y.H.; Kim, J.; Park, C.M. Cold activation of a plasma membrane-tethered NAC transcription factor induces a pathogen resistance response in Arabidopsis. Plant J. 2010, 61, 661-671. [CrossRef]

43. Lechner, E.; Leonhardt, N.; Eisler, H.; Parmentier, Y.; Alioua, M.; Jacquet, H.; Leung, J.; Genschik, P. MATH/BTB CRL3 receptors target the homeodomain-leucine zipper ATHB6 to modulate abscisic acid signaling. Dev. Cell 2011, 21, 1116-1128. [CrossRef]

44. Johannesson, H.; Wang, Y.; Hanson, J.; Engstrom, P. The Arabidopsis thaliana homeobox gene ATHB5 is a potential regulator of abscisic acid responsiveness in developing seedlings. Plant Mol. Biol. 2003, 51, 719-729. [CrossRef] [PubMed]

45. Jiang, W.; Yu, D. Arabidopsis WRKY2 transcription factor mediates seed germination and postgermination arrest of development by abscisic acid. BMC Plant Biol. 2009, 9, 96. [CrossRef] [PubMed]

46. Sakuma, Y.; Liu, Q.; Dubouzet, J.G.; Abe, H.; Shinozaki, K.; Yamaguchi-Shinozaki, K. DNA-binding specificity of the ERF/AP2 domain of Arabidopsis DREBs, transcription factors involved in dehydration- and cold-inducible gene expression. Biochem. Biophys. Res. Commun. 2002, 290, 998-1009. [CrossRef]

47. Lee, S.J.; Kang, J.Y.; Park, H.J.; Kim, M.D.; Bae, M.S.; Choi, H.I.; Kim, S.Y. DREB2C interacts with ABF2, a bZIP protein regulating abscisic acid-responsive gene expression, and its overexpression affects abscisic acid sensitivity. Plant Physiol. 2010, 153, 716-727. [CrossRef]

48. Kim, J.S.; Mizoi, J.; Yoshida, T.; Fujita, Y.; Nakajima, J.; Ohori, T.; Todaka, D.; Nakashima, K.; Hirayama, T.; Shinozaki, K.; Yamaguchi-Shinozaki, K. An ABRE Promoter Sequence is Involved in Osmotic Stress-Responsive Expression of the DREB2A Gene, Which Encodes a Transcription Factor Regulating Drought-Inducible Genes in Arabidopsis. Plant Cell Physiol. 2011, 52, 2136-2146. [CrossRef]

49. Tang, W.; Ji, Q.; Huang, Y.; Jiang, Z.; Bao, M.; Wang, H.; Lin, R. FAR-RED ELONGATED HYPOCOTYL3 and FAR-RED IMPAIRED RESPONSE1 transcription factors integrate light and abscisic acid signaling in Arabidopsis. Plant Physiol. 2013, 163, 857-866. [CrossRef] [PubMed]

50. Van Hengel, A.J.; Barber, C.; Roberts, K. The expression patterns of arabinogalactan-protein AtAGP30 and GLABRA2 reveal a role for abscisic acid in the early stages of root epidermal patterning. Plant J. 2004, 39, 70-83. [CrossRef]

51. Soderman, E.; Mattsson, J.; Engstrom, P. The Arabidopsis homeobox gene ATHB-7 is induced by water deficit and by abscisic acid. Plant J. 1996, 10, 375-381. [CrossRef] [PubMed]

52. Valdes, A.E.; Overnas, E.; Johansson, H.; Rada-Iglesias, A.; Engstrom, P. The homeodomain-leucine zipper (HD-Zip) class I transcription factors ATHB7 and ATHB12 modulate abscisic acid signalling by regulating protein phosphatase 2C and abscisic acid receptor gene activities. Plant Mol. Biol. 2012, 80, 405-418. [CrossRef] [PubMed]

53. Chinnusamy, V.; Ohta, M.; Kanrar, S.; Lee, B.H.; Hong, X.; Agarwal, M.; Zhu, J.K. ICE1: A regulator of cold-induced transcriptome and freezing tolerance in Arabidopsis. Genes Dev. 2003, 17, 1043-1054. [CrossRef]

54. Yamamoto, A.; Kagaya, Y.; Toyoshima, R.; Kagaya, M.; Takeda, S.; Hattori, T. Arabidopsis NF-YB subunits LEC1 and LEC1-LIKE activate transcription by interacting with seed-specific ABRE-binding factors. Plant J. 2009, 58, 843-856. [CrossRef]

55. Brocard-Gifford, I.M.; Lynch, T.J.; Finkelstein, R.R. Regulatory networks in seeds integrating developmental, abscisic acid, sugar, and light signaling. Plant Physiol. 2003, 131, 78-92. [CrossRef]

56. Reyes, J.L.; Chua, N.H. ABA induction of miR159 controls transcript levels of two MYB factors during Arabidopsis seed germination. Plant J. 2007, 49, 592-606. [CrossRef]

57. Tran, L.S.P.; Nakashima, K.; Sakuma, Y.; Simpson, S.D.; Fujita, Y.; Maruyama, K.; Fujita, M.; Seki, M.; Shinozaki, K.; Yamaguchi-Shinozaki, K. Isolation and functional analysis of Arabidopsis stress-inducible NAC transcription factors that bind to a drought-responsive cis-element in the early responsive to dehydration stress 1 promoter. Plant Cell 2004, 16, 2481-2498. [CrossRef] [PubMed]

58. Yanhui, C.; Xiaoyuan, Y.; Kun, H.; Meihua, L.; Jigang, L.; Zhaofeng, G.; Zhiqiang, L.; Yunfei, Z.; Xiaoxiao, W.; Xiaoming, Q.; Yunping, S.; Li, Z.; Xiaohui, D.; Jingchu, L.; Xing-Wang, D.; Zhangliang, C.; Hongya, G.; Li-Jia, Q. The MYB transcription factor superfamily of Arabidopsis: Expression analysis and phylogenetic comparison with the rice MYB family. Plant Mol. Biol. 2006, 60, 107-124. [CrossRef] [PubMed] 
59. Li, J.; Li, X.; Guo, L.; Lu, F.; Feng, X.; He, K.; Wei, L.; Chen, Z.; Qu, L.J.; Gu, H. A subgroup of MYB transcription factor genes undergoes highly conserved alternative splicing in Arabidopsis and rice. J. Exp. Bot. 2006, 57, 1263-1273. [CrossRef]

60. Kang, H.G.; Singh, K.B. Characterization of salicylic acid-responsive, arabidopsis Dof domain proteins: Overexpression of OBP3 leads to growth defects. Plant J. 2000, 21, 329-339. [CrossRef] [PubMed]

61. Kang, H.G.; Foley, R.C.; Onate-Sanchez, L.; Lin, C.; Singh, K.B. Target genes for OBP3, a Dof transcription factor, include novel basic helix-loop-helix domain proteins inducible by salicylic acid. Plant J. 2003, 35, 362-372. [CrossRef] [PubMed]

62. Johnson, C.; Boden, E.; Arias, J. Salicylic acid and NPR1 induce the recruitment of trans-activating TGA factors to a defense gene promoter in Arabidopsis. Plant Cell 2003, 15, 1846-1858. [CrossRef] [PubMed]

63. Zander, M.; La Camera, S.; Lamotte, O.; Metraux, J.P.; Gatz, C. Arabidopsis thaliana class-II TGA transcription factors are essential activators of jasmonic acid/ethylene-induced defense responses. Plant J. 2010, 61, 200-210. [CrossRef] [PubMed]

64. Fonseca, J.P.; Menossi, M.; Thibaud-Nissen, F.; Town, C.D. Functional analysis of a TGA factor-binding site located in the promoter region controlling salicylic acid-induced NIMIN-1 expression in Arabidopsis. Genet. Mol Res. 2010, 9, 167-175. [CrossRef] [PubMed]

65. Thibaud-Nissen, F.; Wu, H.; Richmond, T.; Redman, J.C.; Johnson, C.; Green, R.; Arias, J.; Town, C.D. Development of Arabidopsis whole-genome microarrays and their application to the discovery of binding sites for the TGA2 transcription factor in salicylic acid-treated plants. Plant J. 2006, 47, 152-162. [CrossRef] [PubMed]

66. Choi, J.; Huh, S.U.; Kojima, M.; Sakakibara, H.; Paek, K.H.; Hwang, I. The cytokinin-activated transcription factor ARR2 promotes plant immunity via TGA3/NPR1-dependent salicylic acid signaling in Arabidopsis. Dev. Cell 2010, 19, 284-295. [CrossRef] [PubMed]

67. Zhou, J.M.; Trifa, Y.; Silva, H.; Pontier, D.; Lam, E.; Shah, J.; Klessig, D.F. NPR1 differentially interacts with members of the TGA/OBF family of transcription factors that bind an element of the PR-1 gene required for induction by salicylic acid. Mol. Plant Microbe Ind. 2000, 13, 191-202. [CrossRef]

68. Kang, H.G.; Klessig, D.F. Salicylic acid-inducible Arabidopsis CK2-like activity phosphorylates TGA2. Plant Mol. Biol. 2005, 57, 541-557. [CrossRef]

69. Duan, M.R.; Nan, J.; Liang, Y.H.; Mao, P.; Lu, L.; Li, L.; Wei, C.; Lai, L.; Li, Y.; Su, X.D. DNA binding mechanism revealed by high resolution crystal structure of Arabidopsis thaliana WRKY1 protein. Nucleic Acids Res. 2007, 35, 1145-1154. [CrossRef]

70. Robatzek, S.; Somssich, I.E. A new member of the Arabidopsis WRKY transcription factor family, AtWRKY6, is associated with both senescence- and defence-related processes. Plant J. 2001, 28, 123-133. [CrossRef]

71. Yu, D.; Chen, C.; Chen, Z. Evidence for an important role of WRKY DNA binding proteins in the regulation of NPR1 gene expression. Plant Cell 2001, 13, 1527-1540. [CrossRef]

72. Lai, Z.; Vinod, K.; Zheng, Z.; Fan, B.; Chen, Z. Roles of Arabidopsis WRKY3 and WRKY4 transcription factors in plant responses to pathogens. BMC Plant Biol. 2008, 8, 68. [CrossRef]

73. Chen, L.; Zhang, L.; Yu, D. Wounding-induced WRKY8 is involved in basal defense in Arabidopsis. Mol. Plant Microbe Interact 2010, 23, 558-565. [CrossRef]

74. Hu, Y.; Chen, L.; Wang, H.; Zhang, L.; Wang, F.; Yu, D. Arabidopsis transcription factor WRKY8 functions antagonistically with its interacting partner VQ9 to modulate salinity stress tolerance. Plant J. 2013, 74, 730-745. [CrossRef]

75. Chen, L.; Zhang, L.; Li, D.; Wang, F.; Yu, D. WRKY8 transcription factor functions in the TMV-cg defense response by mediating both abscisic acid and ethylene signaling in Arabidopsis. Proc. Natl. Acad. Sci. USA 2013, 110, E1963-E1971. [CrossRef]

76. Zhang, Z.; Li, Q.; Li, Z.; Staswick, P.E.; Wang, M.; Zhu, Y.; He, Z. Dual regulation role of GH3.5 in salicylic acid and auxin signaling during Arabidopsis-Pseudomonas syringae interaction. Plant Physiol. 2007, 145, 450-464. [CrossRef]

77. Scarpeci, T.E.; Zanor, M.I.; Mueller-Roeber, B.; Valle, E.M. Overexpression of AtWRKY30 enhances abiotic stress tolerance during early growth stages in Arabidopsis thaliana. Plant Mol. Biol. 2013, 83, 265-277. [CrossRef] 
78. Li, J.; Besseau, S.; Toronen, P.; Sipari, N.; Kollist, H.; Holm, L.; Palva, E.T. Defense-related transcription factors WRKY70 and WRKY54 modulate osmotic stress tolerance by regulating stomatal aperture in Arabidopsis. New Phytol. 2013, 200, 457-472. [CrossRef]

79. Wu, H.Y.; Liu, K.H.; Wang, Y.C.; Wu, J.F.; Chiu, W.L.; Chen, C.Y.; Wu, S.H.; Sheen, J.; Lai, E.M. AGROBEST: An efficient Agrobacterium-mediated transient expression method for versatile gene function analyses in Arabidopsis seedlings. Plant Methods 2014, 10, 19. [CrossRef]

80. Song, L.; Huang, S.C.; Wise, A.; Castanon, R.; Nery, J.R.; Chen, H.; Watanabe, M.; Thomas, J.; Bar-Joseph, Z.; Ecker, J.R. A transcription factor hierarchy defines an environmental stress response network. Science 2016, 354, 6312. [CrossRef]

81. Sun, D.; Nandety, R.S.; Zhang, Y.; Reid, M.S.; Niu, L.; Jiang, C.Z. A petunia ethylene-responsive element binding factor, PhERF2, plays an important role in antiviral RNA silencing. J. Exp. Bot. 2016, 67, 3353-3365. [CrossRef]

82. Yoon, E.K.; Yang, J.H.; Lim, J.; Kim, S.H.; Kim, S.K.; Lee, W.S. Auxin regulation of the microRNA390-dependent transacting small interfering RNA pathway in Arabidopsis lateral root development. Nucleic Acids Res. 2010, 38, 1382-1391. [CrossRef]

83. Lewsey, M.G.; Murphy, A.M.; Maclean, D.; Dalchau, N.; Westwood, J.H.; Macaulay, K.; Bennett, M.H.; Moulin, M.; Hanke, D.E.; Powell, G.; Smith, A.G.; Carr, J.P. Disruption of two defensive signaling pathways by a viral RNA silencing suppressor. Mol. Plant Microbe Interact 2010, 23, 835-845. [CrossRef]

84. Morris, K.; Mackerness, S.A.H.; Page, T.; John, C.F.; Murphy, A.M.; Carr, J.P.; Buchanan-Wollaston, V. Salicylic acid has a role in regulating gene expression during leaf senescence. Plant J. 2000, 23, 677-685. [CrossRef]

85. Qin, J.; Ma, X.; Yi, Z.; Tang, Z.; Meng, Y. A transcriptome-wide study on the microRNA- and the Argonaute 1-enriched small RNA-mediated regulatory networks involved in plant leaf senescence. Plant Biol. 2016, 18, 197-205. [CrossRef]

86. De Vleesschauwer, D.; $\mathrm{Xu}$, J.; Hofte, M. Making sense of hormone-mediated defense networking: From rice to Arabidopsis. Front. Plant Sci. 2014, 5, 611. [CrossRef]

87. Lee, S.; Park, C.M. Modulation of reactive oxygen species by salicylic acid in Arabidopsis seed germination under high salinity. Plant Signal. Behav. 2010, 5, 1534-1536. [CrossRef]

88. Yu, Y.; Wang, J.; Li, S.; Kakan, X.; Zhou, Y.; Miao, Y.; Wang, F.; Qin, H.; Huang, R. Ascorbic Acid Integrates the Antagonistic Modulation of Ethylene and Abscisic Acid in the Accumulation of Reactive Oxygen Species. Plant Physiol. 2019, 179, 1861-1875. [CrossRef]

89. Jin, J.; Tian, F.; Yang, D.C.; Meng, Y.Q.; Kong, L.; Luo, J.; Gao, G. PlantTFDB 4.0: Toward a central hub for transcription factors and regulatory interactions in plants. Nucleic Acids Res. 2017, 45, D1040-D1045. [CrossRef]

90. Alazem, M.; Lin, K.Y.; Lin, N.S. The abscisic acid pathway has multifaceted effects on the accumulation of Bamboo mosaic virus. Mol. Plant Microbe Interact 2014, 27, 177-189. [CrossRef]

91. Prasanth, K.R.; Huang, Y.W.; Liou, M.R.; Wang, R.Y.; Hu, C.C.; Tsai, C.H.; Meng, M.; Lin, N.S.; Hsu, Y.H. Glyceraldehyde 3-phosphate dehydrogenase negatively regulates the replication of Bamboo mosaic virus and its associated satellite RNA. J. Virol. 2011, 85, 8829-8840. [CrossRef]

92. Despres, C.; Chubak, C.; Rochon, A.; Clark, R.; Bethune, T.; Desveaux, D.; Fobert, P.R. The Arabidopsis NPR1 disease resistance protein is a novel cofactor that confers redox regulation of DNA binding activity to the basic domain/leucine zipper transcription factor TGA1. Plant Cell 2003, 15, 2181-2191. [CrossRef]

93. Katagiri, F.; Lam, E.; Chua, N.H. Two tobacco DNA-binding proteins with homology to the nuclear factor CREB. Nature 1989, 340, 727-730. [CrossRef]

94. Xiang, C.; Miao, Z.; Lam, E. DNA-binding properties, genomic organization and expression pattern of TGA6, a new member of the TGA family of bZIP transcription factors in Arabidopsis thaliana. Plant Mol. Biol. 1997, 34, 403-415. [CrossRef]

95. Klinedinst, S.; Pascuzzi, P.; Redman, J.; Desai, M.; Arias, J. A xenobiotic-stress-activated transcription factor and its cognate target genes are preferentially expressed in root tip meristems. Plant Mol. Biol. 2000, 42, 679-688. [CrossRef] 